\title{
Corporate Social Responsibility (CSR) in Asia
}

\author{
A Seven-Country Study of CSR Web Site Reporting
}

\author{
WENDY CHAPPLE \\ JEREMY MOON
}

International Centre for Corporate Social Responsibility

\begin{abstract}
This article addresses four hypotheses: (a) that corporate social responsibility (CSR) in Asia is not homogeneous but varies among countries, (b) that the variation is explained by stages of development, (c) that globalization enhances the adoption of CSR in Asia, and (d) that national business systems structure the profile of multinational corporations' CSR. These hypotheses are investigated through analysis of Web site reporting of 50 companies in seven Asian countries: India, Indonesia, Malaysia, the Philippines, South Korea, Singapore, and Thailand. The article concludes that CSR does vary considerably among Asian countries but that this variation is not explained by development but by factors in the respective national business systems. It also concludes that multinational companies are more likely to adopt CSR than those operating solely in their home country but that the profile of their CSR tends to reflect the profile of the country of operation rather than the country of origin.
\end{abstract}

Keywords: corporate social responsibility (CSR); CSR salience/profile; Asia; Web site reporting; globalization; national business systems

This article investigates corporate social responsibility (CSR) reporting in seven Asian countries: India, Indonesia, Malaysia, the Philippines, Singapore, South Korea, and Thailand. It does so through analysis of Web site reporting of CSR by the top 50 companies of each country. The article addresses the following questions:

AUTHORS'NOTE: We would like to thank Eleanor Chambers and Michael Sullivan for their excellent research assistance and contributions to an earlier draft. We are also grateful to Wayne Visser for comments on a draft and to the reviewers of the journal.

BUSINESS \& SOCIETY, Vol. 44 No. 4, December 2005 415-441

DOI: $10.1177 / 0007650305281658$

(C) 2005 Sage Publications 
- Does CSR vary among the seven Asian countries, or is it relatively homogeneous?

- To the extent that any variation is found in the CSR of these countries, is this a function of indicators of development or of their national business systems?

- Is CSR in these countries enhanced or threatened by globalization?

- Do globalizing companies export their CSR to these countries, or do they adapt to the national styles of CSR in the respective countries?

The context for this research is that a great deal of research has now been conducted on CSR in Western countries but relatively little focuses on Asia (but see Birch \& Moon, 2004). Moreover, relatively little CSR research has compared national systems of CSR (but see also Langlois \& Schlegelmilch, 1990; Maignon \& Ralston, 2002; Matten \& Moon, 2004; Rossouw, 2005; Ryan, 2005; van Tulder \& Kolk, 2001; Wieland, 2005), and even less has been comparative within Asia (but see Ramasamy \& Woan Ting, 2004; Welford, 2004).

Although the concept of CSR has been extant in business and business research and education for many decades, it has enjoyed something of a revival in the past decade, as noted even by such skeptics as Martin Wolf (2002), the chief economics correspondent for the Financial Times, who commented that "corporate social responsibility is an idea whose time has come" (p. 62) and Clive Crook (2005), deputy editor of The Economist, who noted that "CSR has blossomed as an idea" (p. 1). CSR is conventionally defined as the social involvement, responsiveness, and accountability of companies apart from their core profit activities and beyond the requirements of the law and what is otherwise required by government. However, this definition is becoming more and more problematic as various business cases for CSR are being made (McWilliams \& Siegel, 2001), governments are deploying incentives for CSR (Moon, 2004), and compliance with the law in a variety of global jurisdictions is emerging as a CSR issue (Sharfman, Shaft, \& Tihanyi, 2004). More generally, CSR is being identified by its underlying strategic purpose (e.g., legitimacy, responsibility for social externality, competitive advantage), by its drivers (e.g., market, social regulation, soft government regulation), and by its manifestations (e.g., economic, legal, ethical, discretionary; see Carroll, 1998). Moreover, it has also been recognized that in addition to the explicit or programmatic variants of CSR best associated with the AngloAmerican business systems, business social responsibility can also reflect implicit conformance with societal norms of business behavior and consensually developed regulatory frameworks (Matten \& Moon, 2004). As explained in the Method section, we do not impose a strict definition of 
CSR onto the analysis; rather, we use the investigation to elicit the different meanings and practices of CSR in the seven different countries.

Evidence of CSR as a component of business-society relations is manifest in a variety of indicators within companies (e.g., staff, processes, codes and budgets devoted to CSR); corporate communications (e.g., Web site reporting, free-standing CSR reports, corporate branding); core stakeholder demands from consumers, employees, and investors; and wider stakeholder demands and pressure from nongovernmental organizations (NGOs), the media, and governmental organizations. Moreover, it is also evident in the development of a range of business coalitions to advance CSR (e.g., the Global Business Coalition on HIV/AIDS), to report CSR (e.g., the Global Reporting Index), and to measure CSR (e.g., the Dow Jones Sustainability Index). Most of the evidence that has been documented, in the English language at least, relates to North America, Western Europe, Australasia, and Japan. There is relatively little research on the rest of Asia. Conventionally, it is assumed that CSR is largely a Western phenomenon, because:

There are numerous obstacles to achieving corporate responsibility, particularly in many developing countries where the institutions, standards and appeals system, which give life to CSR in North America and Europe, are relatively weak. (Kemp, 2001, p. 1)

However, there are some suggestions that the sort of drivers that have been associated with the new developments of CSR in Western Europe and North America are also apparent in parts of Asia. Davies (2000) reported on the growth of Asian consumer expectations of socially responsible business. Business watchdogs, be they ethical investment organizations or NGOs, are increasingly active in monitoring and reporting on the behavior of multinational corporations (MNCs) in Asia. This brings us to the first two research questions specified (above) concerning the variation or homogeneity of CSR in Asia and the significance of development factors or national business systems (Whitley, 1992) in explaining this. Moreover, the challenges of globalization, particularly for Western companies operating in Asia and other parts of the developed world, have included the challenges of behaving responsibly according to the norms of their own and their host countries. This informs our third and fourth questions concerning the comparative CSR of international and domestic companies and the nature of CSR imported by international companies into the seven Asian countries.

The article continues by setting out four related hypotheses concerning CSR in Asia. It proceeds to present the methodology deployed and the 
results of the analysis. It concludes by discussing the role of national business systems in shaping CSR behaviors.

\section{HYPOTHESES}

\section{Hypothesis 1: CSR Varies Among Asian Countries}

This hypothesis is derived from research findings that show marked differences in CSR and its reporting even among such similar systems as the United States and Western Europe (Habisch, Jonker, Wegner, \& Schmidpeter, 2004; Maignan \& Ralston, 2002; Matten \& Moon, 2004). We therefore hypothesize that there are significant differences in CSR among the seven Asian countries in this study. We hypothesize that the variance in CSR practices will be apparent at five levels. First, we hypothesize that there will be variation in the proportion of firms that report themselves as CSR active. We refer to this as the level of CSR penetration. Second, we hypothesize that there will be variation in the extent of CSR reporting - that is, the amount of communication provided. Third, we hypothesize that there will be differences in the broad types of CSR activities (community involvement, products and processes, employee relations), which we call waves of CSR. These waves reflect the alignment of CSR to the core business of the corporation. Fourth, we hypothesize that there will be variance in the issues engaged in, which reflect salient national business-society agendas. Fifth, we hypothesize there will be variance in the modes of CSR. Here we expect differences in how CSR is employed, thereby reflecting different levels of institutionalization within the companies.

\section{Hypothesis 2: CSR in Asia is Dependent on Development}

Often, it has been assumed that the emergence of CSR is a function of economic and social development. This follows from the observation that CSR appears to have taken off faster in Westernized than in other countries, as illustrated by Kemp (2001). It is assumed that higher levels of development lead to higher CSR because of higher levels of resources and greater awareness of issues, and thus, Asia lags behind the West in CSR penetration (KPMG, 2005; Welford, 2004). However, following Matten and Moon (2004), one might counterargue that CSR is often implicit in Asian countries and more a function of national business systems rather than development per se. Given the great variety of Asian national social, political, and economic configurations, it could be argued that the cate- 
gory of Asia is simply too broad and that patterns of CSR are grounded in nationally specific norms of business-society relations, corporate governance, governmental responsibilities, and broader norms of societal governance, for example. Given that differences in historical attitudes to government, long-run government-business relations, and public policy designs are used to explain differences in the CSR of countries whose social and cultural heritages are as similar as the United Kingdom and United States (Moon, 2003), it would seem to follow that the greater differences among our seven Asian countries are more significant for informing CSR differences than are their stages of development.

We therefore test this hypothesis by examining the relationship between development and CSR activity. We measure development in three ways: (a) economic development, (b) social development, and (c) economic structure. In combination, they present clusters of characteristics rather than indices and, therefore, analysis here is necessarily rather tentative. We hypothesize that the higher the development levels, the higher the CSR penetration.

Hypothesis 3: The Adoption of CSR in Asia Will Be Enhanced by Globalization

It could be hypothesized that globalization will encourage CSR. Two sorts of arguments underpin this hypothesis. First, as globalization in Asia is largely a function of the increased activity of Western businesses (which we assume to have higher levels of CSR), we might expect the spread of CSR into Asia. This would arise because of increased operations of Western companies in Asia, whether through export or production, which would entail these companies bringing their CSR policies to Asian countries and either applying them to (geocentric approach; Perlmutter, 1969) or adapting them to (polycentric approach; Perlmutter, 1969) the national circumstances.

Alternatively, it could be argued that the very nature of internationalization, by companies of any nationality, leads to an increase in CSR. This could be expected to result from two sorts of factors. First, it might be envisaged that as businesses trade in foreign countries, they see the need to establish their reputations as good citizens in the eyes of new host populations and consequently will engage in CSR as part of this process. Second, it could be argued that the emerging systems of world economic governance create incentives for greater CSR. This could result from the increase in global business watchdogs (e.g., NGOs, ethical investment firms) and in standards of business practice (including CSR) associated with, for example, the World Bank, the Organization for Economic 
Cooperation and Development, and the United Nations Global Compact (McIntosh, Waddock, \& Kell, 2004). Here, the incentives are less specific to any one particular set of new stakeholders but more in the nature of the changing institutional context of international business (Braithewaite \& Drahos, 2000).

To test the hypothesis, we first consider the possible effect of foreign direct investment into a country on its level of CSR penetration. If, notwithstanding domestic Asian traditions of business philanthropy, the current trends in CSR are distinctly Western phenomena, it might be argued that the higher the level of investment into a country from abroad, the higher the likely influence of foreign practices on domestic companies.

Second, one could argue that CSR penetration is correlated with the identity of the countries with which it trades. If a corporation trades principally with Westernized nations, one might expect them to raise their levels of CSR activity to coincide with those of their trading partner. Therefore, it could be argued that there is a positive correlation between penetration of CSR and the percentage exported to the United States as a proxy for the trade to Western nations. Third, we hypothesize that the multinational companies will be associated with higher levels of CSR penetration than those domestically headquartered companies that do not operate outside the respective countries.

Hypothesis 4: National Business Systems Structure the Character of CSR of MNCs

Following Matten and Moon (2004), we argue that notwithstanding the effect of MNCs on the penetration and extent of CSR, the specific national CSR profile can be explained by factors discussed in the national business systems or societal-effect approach (Maurice \& Sorge, 2000; Whitley, 1992, 1999, 2002). In particular, the organization of market processes will shape CSR issues such as labor issues, environmental liability, and product stewardship. Thus, the authoritative coordination and control systems will vary between various national business systems. In particular, this will affect how employee-employer relations are organized, the degree to which trust governs relations, and the discretion in the task environment granted to employees.

These components are shaped by political, financial, educational, and cultural institutions, which vary from country to country. We argue, as in Matten and Moon (2004), that differences in what CSR actually means and how it manifests itself differ from country to country. Hence, despite the process of globalization and the harmonization of management 
processes and structure, national business systems still remain distinct and hence will shape CSR. However, finding measures of these aspects is very difficult. Therefore, in terms of Perlmutter's (1969) classification, we therefore hypothesize that in terms of CSR, multinational companies will adopt a polycentric approach by adapting CSR approaches to national business systems and salient social issues, rather than the geocentric approach suggested by Sharfman et al. (2004). Hence, the question arises that if international companies are providing the key drivers for CSR, does this entail the importation of foreign issues and modes?

\section{METHOD}

\section{Selection of Countries}

The selection of countries for a study of CSR in Asia is clearly a key methodological decision. Our aim was to combine the representativeness of characteristics of Asian countries with the manageability of data gathering and analysis. The inclusion of seven countries is itself something of an achievement exceeding comparable studies: Welford (2004) included six and KPMG (2005) included five Asian countries.

Japan was excluded from the full analysis because, in the past 50 years, its economy has been relatively well integrated into the contemporary directions of international business and because its CSR has been relatively well established (Fukukawa \& Moon, 2004). Indeed the KPMG (2005, p. 11) research suggests that it is among the world leaders in corporate responsibility reporting. To this extent, we consider it an outlier. China was omitted on the assumption that its legacy of state-owned business would not be conducive to CSR and that it would, by definition, be an outlier. There were also doubts as to the extent of English-language Web sites. We considered that a sample of Hong Kong-based companies would be unrepresentative of Chinese business overall.

The seven selected countries represent a range in terms of the size of the population, from India (over 1 billion) and Indonesia (over 240 million) to Singapore (just over 4 million). The selection also represents a range in terms of economic development, including two notable Asian Tigers, Singapore and South Korea, as well as slower developing countries, such as Indonesia and the Philippines.

The sample also represents a range of religious affiliation with India predominantly Hindu, Indonesia and Malaysia predominantly Moslem, Thailand predominantly Buddhist, Singapore predominantly Buddhist 
and Taoist, South Korea predominantly Buddhist and Christian, and the Philippines predominantly Christian.

The sample represents a range of political experiences. India has had a democratic government and a relatively liberal polity since independence, whereas Malaysia and Singapore have democratic governments (both with long periods of rule by one party and prime minister) with less liberal polities. Thailand has had periods of democratic politics punctuated by periods of military rule. Indonesia, the Philippines, and South Korea have had long periods of military/authoritarian rule followed by short periods of relatively fragile democracy.

As a result, perhaps excepting India which has witnessed some improvements in corporate governance, all the countries share what is often regarded as an Asian characteristic of "weak institutions and poor property rights" (Mallin, 2004, p. 173; see also Rodan, 2002). In some systems, this simply reflects the impacts of military or authoritarian rule in creating opportunities for cronyism.

\section{Selection of Corporations}

The top 50 companies (by operating revenue in August 2002) with corporate Web sites in each of the seven Asian countries were analyzed. Where a company did not have a corporate Web site, we moved down the list until we had a sample of 50 companies per country-the method employed by Maignan and Ralston (2002).

The Web site of each company was examined for any CSR activities. We do not impose a rigid definition of CSR, as we wish to see the data inform emergent CSR profiles in different countries. Instead, we take all company initiatives, codes, and policies that involve positive stakeholder interaction, or impact, to be a CSR activity. Using the grounded theory (Glaser \& Strauss, 1967), we then provide emergent profiles of CSR activities within the countries. Where such activities were found, the companies were labeled as CSR companies and the CSR Web entries were subjected to further analysis. The CSR of these companies was classified in various ways: extent, institutionalization (in terms of dedicated CSR organization and report), the balance of different waves of CSR (i.e., community involvement, socially responsible products and processes, socially responsible employee relations), the issues that made up these waves, and the modes deployed to enact CSR. By mode, we mean the way in which CSR is engaged in, ranging from add-on philanthropic modes to more institutionalized methods, such as partnership, volunteering, or trust fund activity. 


\section{Web Site Reporting}

It could be objected that company Web site reports are not an appropriate vehicle for this sort of analysis. First, it could be assumed that in Asia, Web sites are not as widely used for business communication as in, say, Western systems. This could be premised on the much smaller proportions of the Asian populations that use the Internet than in Western countries. This is largely a function of relative wealth, as the main barrier to Internet use tends to be the high costs of connection, which means that "most companies in Asia will not catch up until the costs of connecting to the internet come down" (Belson, 2000, p. 5). Logging on in South Korea, for example, is three times as expensive as in the United States (Belson, 2000). Moreover, in some Asian countries, Internet availability is restricted by state-dominated telecommunications systems and restrictive regulations over its use (Johnson, 2000). It could therefore follow that in countries with low Internet use, companies will use other means to disseminate information about their CSR.

Only two countries, Singapore (which had the highest usage overall but which has relatively restrictive Internet regulations) and South Korea, have comparable Internet usage to the United Kingdom. At the other end of the spectrum in Indonesia only $0.2 \%$ of the population comprised Internet users (Central Intelligence Agency, 2000). We were, nonetheless, easily able to identify 50 companies per country with English-language Web sites. The percentages of companies in the first 50 companies listed that did not have corporate Web sites were as follows: India, 16\%; South Korea, 0\%; Thailand, 18\%; Singapore, 16\%; Malaysia, 6\%; the Philippines, $18 \%$; and Indonesia, $12 \%$.

It still could be countered that because of the lower Internet user rate in Asia, companies would not be inclined to invest as much in their Web sites in general and for CSR purposes in particular. However, it should also be recognized that emerging markets' information and computer technology growth rates are comparatively high, averaging $28 \%$ in the period from 1992 to 1999 (de la Torre \& Moxon, 2001, p. 633). Second, it should be recognized that CSR reporting by large corporations is not only for society at large but also for a range of stakeholders, be they investors, actual and potential employees, NGOs, or business customers (Esrock \& Leichty, 1998).

It could be objected that the findings would be unrepresentative of national business patterns because only very large companies would be analyzed. This is, of course, true. However, most findings for CSR in Western companies are also of very large corporations (e.g., Maignon \& Ralston, 2002). Although in neither case should the findings be regarded 
as fully representative of all business, it remains the case that very large companies tend to be agenda setters in CSR and have relatively greater financial and other resources to devote to it. In recent years, this has gained added substance through the role of large corporations in providing assurance about the social responsibility of their supply chains, thereby affecting smaller organizations.

Third, it could be objected that CSR reporting is not necessarily a reflection of CSR policies and practice. On one hand, CSR reporting may exaggerate CSR practice and performance, and on the other, it might underestimate it. As the business case for CSR acquires more prominence, the possibility of CSR being related to marketing and reputational branding strategies increases (Adams, Hill, \& Roberts, 1998; Hooghiemstra, 2000). Indeed, given the visibility of large corporations to stakeholder scrutiny, there may even be an added incentive for CSR reporting in Asia as a means of anticipating criticism of their environmental, human rights, and labor standards, for example, among Western stakeholders. Notwithstanding such developments, our point is that the reputational damage a company would face if it had gone out of its way to claim to be following socially responsible practices and was then found to be acting irresponsibly would be greater than if it had not made the claims in the first place, as illustrated by the experience of Nike. Conversely, CSR may be underreported in companies that have long regarded their social responsibility as part and parcel of business or that describe certain components of CSR in other ways. Some companies may include reference to their CSR only in their financial reports. However, given that one of the key themes in CSR is its conspicuous reporting, we would expect this possibility to be decreasingly likely and, in any case, unlikely to be differentially reported across countries.

The company Web site offers various advantages for this sort of comparative study. It enables remote study of business in Asia. Although the layout and style of Web sites vary enormously, they offer a functionally uniform unit of analysis in that all represent an official presentation of companies' policies and practices as opposed to representing the interpretation of these by, say, any one company official.

In terms of analyzing the extent or coverage that was devoted to CSR reporting, we distinguish between those that devote relatively extensive attention to CSR from those that treat it on a more cursory level. It is assumed here that, in general terms, the greater the extent of reporting, the more engaged the company is with CSR and the more seriously it is taken therein. It is difficult to come up with a uniform unit of analysis with which to precisely specify the extent of CSR reporting. This is because of the range of Web site reporting styles and the fact that although some of 
the reports were in the context of general company communications, others were dedicated reports. We simply distinguish those companies whose extent of reporting was minimal - that is, 1 to 2 pages; medium — that is, 3 to 10 pages; and extensive - that is, more than 10 pages. Although these indicators might seem arbitrary in nature, they were applied consistently across the sample to provide comparison. These categories were used to give an overall feel for the relationship between CSR penetration and levels of reporting rather than the content per se.

To analyze the content, we follow Moon (2002) by distinguishing three waves of CSR: community involvement, socially responsible production processes, and socially responsible employee relations. Issues were identified from the Web sites and were categorized into the three waves. Community involvement refers to the traditional assumption about CSR that it is removed from the main business activity and is outside the firm. Included in the community-involvement wave, we include general community issues, agriculture, local economic development, arts and culture, community development, education and training, environment and conservation, health, housing, religion, sport, welfare (including poverty and emergency relief), youth and children-related projects, and other. Although this is often assumed to only mean philanthropy, there might be more engaged forms of community involvement through partnerships, sponsorships, employee volunteering, and strategic alliances. Therefore, it is important that these issues are also analyzed alongside these modes of involvement (see below).

The second two waves reflect a threshold change in the conceptualization of CSR in that it becomes the way in which the company does business rather than how it uses its profits. Socially responsible production refers to the ability of the company to demonstrate that both its supply chain and on-site operations are conducted in a socially responsible fashion. This includes issues relating to the environment, health and safety, human resources, and ethics. The final wave, employee relations, pertains to the issues of employee welfare and employee engagement. Socially responsible employer relations refer to the status of the workforce as a stakeholder in the context of company decision making and the development of CSR practices and policies. There is no necessary order in these waves, although, empirically, community involvement has tended to be the dominant wave.

In coding modes, we distinguish those that use the relatively traditional philanthropic mode from those that better institutionalize and embed the ways in which their CSR is employed. By engaging in partnerships, sponsor relationships, adopting CSR codes, and encouraging employee volunteering, companies build their CSR into mainstream activities; activities 
become less philanthropic and more about stewardship. The case of foundations was a lot more difficult to conceptualize, as although they are, by definition, institutions with processes, rules, and budget parameters, they also remove the CSR from the company itself (Moon, 2003).

The CSR activities of these companies were coded by two researchers and moderated by an additional two. Overall, there was general agreement between the researchers. The modes and issues were coded at the individual issue level for each company and then were aggregated to provide the overall wave profile. These waves do not enable a fine representation of seven national CSR systems. The composition of each wave does not necessarily remain constant, and there are some points of overlap (e.g., when the choice of community partnership reflects employee preferences and participation).

\section{Indicators of Globalization}

We envisage that internationalization can affect CSR activities in several ways. We investigate the impact on CSR through three potential explanatory variables: the levels of direct foreign investment and international export patterns to assess whether globalization enhances CSR (Hypothesis 3) and the domestic/international status of companies (Hypothesis 4). International firms consist of two cohorts: those companies with headquarters based within the country in question but that export to other countries and those with headquarters based in a country other than that in question and that operate in numerous countries. The domestic cohort consists of companies that have their headquarters based within the country in question and that operate solely within that country.

\section{Indicators of Development}

We adopt three indicators to compare the stages of development of the countries concerned. The first of these is economic development (gross national product [GNP] per capita), which is taken as a measure of wealth. The second characteristic is social development. The measurement of social development is always problematic, as it is more difficult to conceptualize and operationalize. We select two proxies: life expectancy (positively associated with physical well-being) and adult literacy (positively associated with political participation). Our third characteristic is that of economic structure. We construct a measure that reflects the balance of economic structure in the seven countries. One might hypothesize that higher agricultural or rural industry would correlate negatively with CSR, as the organizational resources associated with CSR might be less 
widespread. Those countries with a higher service sector could be expected to correlate positively with CSR, as these firms tend to be more conscious of their consumer image than their industrial counterparts.

\section{RESULTS}

We now turn to the presentation of the results of the analysis.

\section{Hypothesis 1: CSR Varies Among Asian Countries}

As indicated above, we investigated variation of CSR among Asian countries according to five variables: penetration of CSR among companies in each country, the extent of CSR reporting within these companies, the waves of CSR reflected in national profiles, the CSR issues underpinning these, and the modes of CSR deployed therein.

The Penetration of CSR Reporting in Asia

As indicated in Table 1, there is a great variation in the penetration of CSR reporting among the seven countries. The proportion of CSR companies in India (72\%) is 3 times that in Indonesia (24\%). Overall, the standard deviation was 0.1624 . This gives clear substance to the view that there is no one Asian pattern of CSR and that there is no case here for rejecting Hypothesis 1. In passing, we note that this represents a slightly greater range than found in the Maignon and Ralston (2002, p. 504) study of CSR reporting in Europe and the United States where the highest national CSR score was 66\% (the United Kingdom) and the lowest was also $24 \%$ (the Netherlands). In subsequent analysis, those companies that demonstrated evidence of CSR reporting are designated as CSR companies.

\section{The Extent of CSR Reporting Within Asian CSR Companies}

We next investigated the extent of coverage that each CSR company devoted to its CSR reporting to distinguish those that accord it relatively extensive attention from those who treat it more cursorily. It is assumed here that, in general terms, the greater the extent of the reporting, the more engaged the company is with CSR and the more seriously it is taken therein. Table 1 again indicates a wide range of experience, from India where only one in six CSR companies reported at the minimal level to Indonesia where three quarters of CSR companies' reporting was mini- 
Table 1

The Penetration and Extent of Corporate Social Responsibility (CSR) Reporting in Asia

\begin{tabular}{|c|c|c|c|c|}
\hline \multirow[b]{2}{*}{ Country } & \multirow{2}{*}{$\begin{array}{c}\text { Penetration of } \\
\text { CSR Reporting in } \\
\text { Companies Per Country }(\%)\end{array}$} & \multicolumn{3}{|c|}{$\begin{array}{c}\text { Extent of CSR Reporting of } \\
\text { CSR Companies Per Country (\%) }\end{array}$} \\
\hline & & Minimal & Medium & Extensive \\
\hline India & 72 & 17 & 47 & 36 \\
\hline South Korea & 52 & 27 & 46 & 27 \\
\hline Thailand & 42 & 24 & 62 & 14 \\
\hline Singapore & 38 & 42 & 42 & 16 \\
\hline Malaysia & 32 & 25 & 50 & 25 \\
\hline The Philippines & 30 & 29 & 36 & 36 \\
\hline Indonesia & 24 & 9 & 9 & 18 \\
\hline Seven-country mean & 41 & 29 & 44 & 27 \\
\hline Standard deviation & 0.1624 & & & \\
\hline
\end{tabular}

mal. Overall, though, the percentage of companies reporting their CSR extensively was relatively low. In no country did a majority of CSR companies report CSR extensively, and in only two cases, India and the Philippines, did more than a third report it extensively.

We also investigated whether the findings for the penetration of CSR within each country correlate with the extent of CSR reporting within the CSR companies of the respective countries. However, it did not follow that greater penetration of CSR among companies makes for greater levels of CSR reporting. No statistically significant relationship was found (Spearman correlation $=.250$ ).

Another indicator of the seriousness with which companies take CSR is their readiness to produce a dedicated CSR report. However, these were rare in all seven countries (mean $=2 \%$, with the greatest level of $8 \%$ in South Korea). This represents relatively low levels of CSR institutionalization (a similar sample in Japan yielded $90 \%$ of companies with some sort of a free-standing report; Fukukawa \& Moon, 2004).

National Profiles of CSR Waves, Issues, and Modes

We continue to investigate the hypothesis of the variation of CSR among Asian countries by turning from quantitative indicators of CSR in Asia to consider the more qualitative indicators of the profile of CSR in each country. 
Table 2

National Waves of Corporate Social Responsibility

\begin{tabular}{lccc}
\hline & $\begin{array}{c}\text { \% Companies } \\
\text { Reporting Community } \\
\text { Involvement }\end{array}$ & $\begin{array}{c}\text { \% Companies } \\
\text { Reporting Production } \\
\text { Processes }\end{array}$ & $\begin{array}{c}\text { \% Companies } \\
\text { Reporting Employee } \\
\text { Relations }\end{array}$ \\
\hline India & 67 & 58 & 31 \\
South Korea & 42 & 54 & 12 \\
Thailand & 71 & 19 & 10 \\
Singapore & 47 & 11 & 21 \\
Malaysia & 69 & 50 & 19 \\
The Philippines & 71 & 29 & 0 \\
Indonesia & 27 & 27 & 27 \\
Seven-country mean & 59 & 39 & 18 \\
\hline
\end{tabular}

We first delineate broad types of activities that CSR companies that provided medium or extensive CSR reporting (derived from Table 1) in each country are engaged in and follow Moon (2002) in distinguishing three waves of CSR: community involvement, socially responsible production processes, and socially responsible employee relations. As we noted above, these waves do not enable a detailed representation of CSR as the composition of each wave is not necessarily constant and there are points of overlap. Table 2 presents the proportion of companies in each country for each wave of CSR activity, and Figure 1 provides a pictorial representation.

In very general terms, the findings confirm Moon's (2002) proposition that community involvement is the most established form of CSR and is being followed by successive second and third waves of socially responsible production processes and employee relations. In no country do more than a third of companies engage in socially responsible employee relations as part of their CSR. The general pattern is most clearly reproduced in the cases of India and Malaysia. However, there is also considerable variation. Thailand and the Philippines lag behind India and Malaysia, giving very little attention to CSR in employee relations. Two countries, South Korea and Indonesia, depart from the pattern of prioritization of community involvement. In South Korea, this is because socially responsible production processes represent the most significant wave. In Indonesia, each wave seems to receive equally low attention.

We now turn to investigate the specific issues of which these waves are composed. Table 3 summarizes the issues prioritized in CSR reporting in each of the seven Asian countries. Generally speaking, education and 


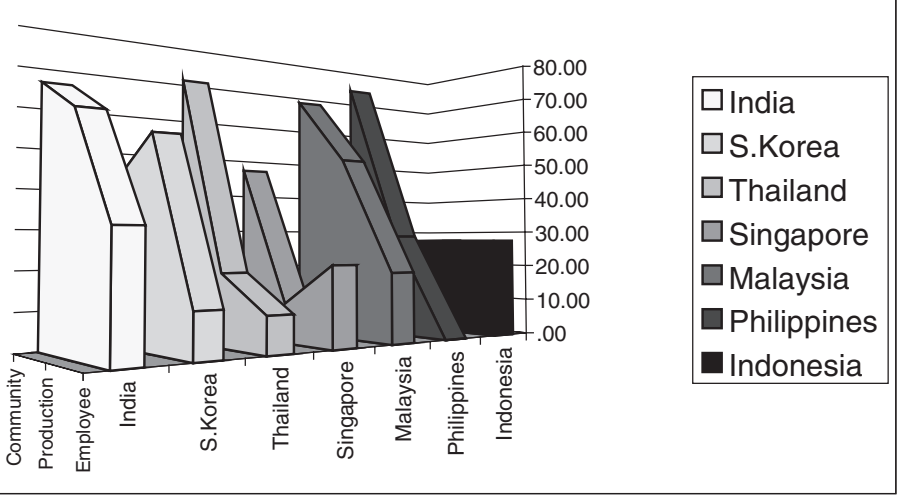

Figure 1. National Waves of Corporate Social Responsibility Reporting

training seem to be the most important issue across all countries. Beyond that, there is considerable variation.

India is the country that most extensively reports its CSR. Its community involvement consists primarily of community development, education and training, and health and disability. India was also the country in which both the second and third waves were the largest. The second wave, production processes, consists primarily of environmental responsibility and health and safety, and the third wave, employee relations, is mainly concerned with employee welfare.

South Korea, the country with the second greatest penetration of CSR, features the environment and conservation, education and training, and welfare in the community-involvement wave. The environment was also foremost in the production-processes wave. All of those companies reporting CSR in employment relations specified employee welfare and employee engagement.

Thailand and Singapore have similar levels of CSR penetration, but their issue profiles differ. Although the main community issues for both are education and training, in Thailand, other prominent issues are environment and conservation, arts, and youth, whereas for Singapore, they are health, disability, and welfare. Moreover, Singapore has a more prominent third wave that consists principally of employee welfare. It appears that the Singapore CSR is addressed to more general societal and employee welfare, whereas the Thai CSR is directed more selectively.

Although Malaysia and the Philippines share similar levels of CSR penetration, Malaysia has much more substantial second and third waves 
Table 3

National Profiles of Corporate Social Responsibility: Waves, Issues, and Modes

\begin{tabular}{|c|c|c|c|}
\hline Country & Waves & Most Frequent Issues & Main Modes \\
\hline \multirow[t]{3}{*}{ India } & $\mathrm{CI}$ & $\begin{array}{l}\text { Community development; education } \\
\text { and training; health and disability }\end{array}$ & $\begin{array}{r}\text { Philanthropy; } \\
\text { partnerships }\end{array}$ \\
\hline & $P \& P$ & Environment; health and safety & Codes \\
\hline & ER & Employee welfare & Sponsorship; codes \\
\hline \multirow[t]{3}{*}{ South Korea } & $\mathrm{CI}$ & $\begin{array}{l}\text { Environment and conservation; educa- } \\
\text { tion; welfare }\end{array}$ & Philanthropy \\
\hline & $\mathrm{P} \& \mathrm{P}$ & Environment & Codes \\
\hline & ER & $\begin{array}{l}\text { Employee welfare; employee } \\
\text { engagement }\end{array}$ & Philanthropy \\
\hline \multirow[t]{3}{*}{ Thailand } & $\mathrm{CI}$ & $\begin{array}{l}\text { Education and training; environment } \\
\text { and conservation; arts; youth }\end{array}$ & $\begin{array}{r}\text { Philanthropy; } \\
\text { foundations }\end{array}$ \\
\hline & $\mathrm{P} \& \mathrm{P}$ & Environment & Codes \\
\hline & ER & & Philanthropy \\
\hline \multirow[t]{3}{*}{ Singapore } & $\mathrm{CI}$ & $\begin{array}{l}\text { Education and training; health and dis- } \\
\text { ability; welfare }\end{array}$ & \\
\hline & $\mathrm{P} \& \mathrm{P}$ & Environment & Codes \\
\hline & ER & Employee welfare & Philanthropy \\
\hline \multirow[t]{3}{*}{ Malaysia } & $\mathrm{CI}$ & $\begin{array}{l}\text { Environment and conservation; educa- } \\
\text { tion and training; welfare }\end{array}$ & \\
\hline & $\mathrm{P} \& \mathrm{P}$ & Environment & Codes \\
\hline & ER & Employee welfare & $\begin{array}{r}\text { Philanthropy; } \\
\text { foundations }\end{array}$ \\
\hline \multirow[t]{3}{*}{ The Philippines } & $\mathrm{CI}$ & $\begin{array}{l}\text { Environment and conservation; educa- } \\
\text { tion and training; community } \\
\text { development }\end{array}$ & \\
\hline & $\mathrm{P} \& \mathrm{P}$ & & \\
\hline & ER & & \\
\hline \multirow[t]{3}{*}{ Indonesia } & $\mathrm{CI}$ & $\begin{array}{l}\text { Agriculture and local economic devel- } \\
\text { opment; community development; } \\
\text { religious organizations }\end{array}$ & \\
\hline & $\mathrm{P} \& \mathrm{P}$ & Environment & Codes; voluntary \\
\hline & ER & $\begin{array}{l}\text { Employee welfare; employee } \\
\text { engagement }\end{array}$ & $\begin{array}{l}\text { Volunteering; sponsor- } \\
\text { ship; philanthropy }\end{array}$ \\
\hline
\end{tabular}

Note: $\mathrm{CI}=$ community involvement $\mathrm{P} \& \mathrm{P}=$ products and processes $\mathrm{ER}=$ employee relations.

of CSR. Community involvement in the Philippines primarily consists of the environment and conservation, education and training, and community development. Although CSR in Malaysia shares attention to the environment and conservation and to education and training, it also gives attention to the issue of welfare.

Not only does Indonesia have the lowest levels of CSR penetration, but it also has the lowest levels of community involvement. Moreover, the issues here are also distinctive with an emphasis on agriculture and local 
economic development, community development, and supporting religious organizations. Unusually, Indonesia's second and third waves are comparable to the first. The second wave consists primarily of environmental codes and the third both of employee welfare and engagement. The findings for Indonesia should be interpreted with some caution given its relatively low number of CSR companies $(n=12)$.

Third, we compare the CSR profile in the seven countries with reference to the modes by which programs are deployed on the assumption that the extent to which systematic, rather than philanthropic, modes are deployed is indicative of greater levels of institutionalization of CSR. Table 3 also presents the main CSR modes deployed within each country. It should be noted here that overall, there is a great emphasis on philanthropic modes rather than the more systematic ones, which confirms Welford's (2004) finding of much less institutionalization of CSR in Asia than in Europe.

As might be expected from the foregoing, India is the country that deploys the most systematic modes, particularly through community partnerships, product codes, and employee relations codes. The Philippines also exhibits a variety of systematic modes of community involvement, particularly through partnerships and foundations. Companies in all countries except the Philippines report using codes in the area of products and processes. Beyond that, philanthropy is the main mode of CSR in the other countries.

Thus, CSR reporting in Asia varies nationally by penetration into companies, the extent of reporting within these companies, and its profile in terms of CSR waves and issues. There is less variation, however, in the modes deployed to deliver the CSR.

\section{Hypothesis 2: CSR in Asia is Dependent on Development}

We analyzed whether national levels of CSR reporting penetration (Table 1) are explained by the individual variables of economic development, social development, or the balance of economic sectors.

The significance of national levels of GNP per capita for CSR was examined on the assumption that a higher level of wealth would reflect relatively greater resources that could be reinvested in society through CSR. There was no statistically significant correlation between GNP and CSR penetration. CSR penetration is almost perfectly inelastic with regard to GNP. Two cases that underline this finding are India, which is relatively poor and has the highest levels of CSR reporting, and Singapore, which is the richest but only the median CSR country out of our seven-fold sample. No statistically significant relationships were found 


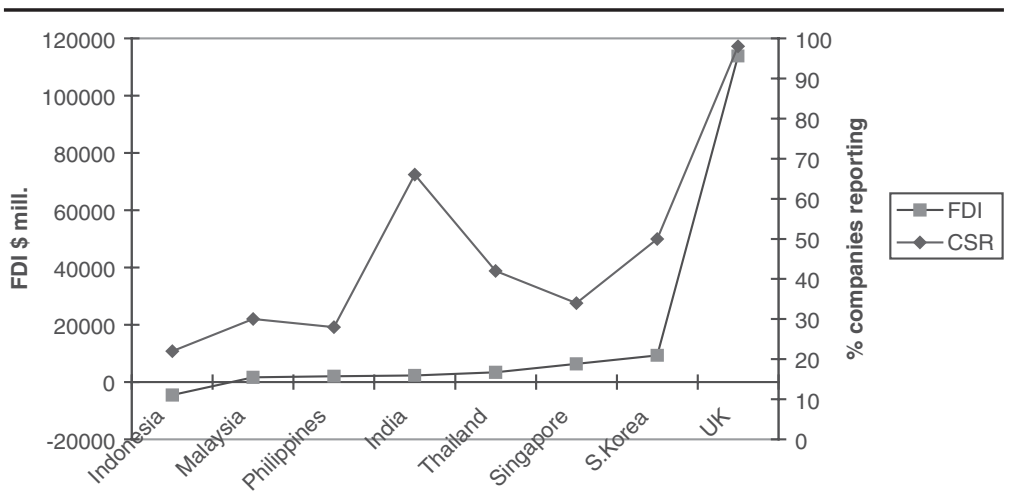

Figure 2. The Relationship Between Direct Foreign Investment and Corporate Social Responsibility

between our two proxies for social development, life expectancy and adult literacy, and CSR penetration.

We then investigated any relationship between CSR and the balance of economic sectors in the seven countries on the assumption that large service sectors would correlate positively with CSR, as these firms tend to be more conscious of their consumer image than their agricultural and industrial counterparts and have the organizational resources to invest in CSR and its reporting. No relationship was found here between CSR penetration and national economic sectoral composition.

In summary, our results suggest that the hypothesis can be rejected. When taken in conjunction with the findings of the national profile of CSR (above), we conclude that there is a reasonable basis for proposing that CSR in Asia is dependent on national factors.

\section{Hypothesis 3: The Adoption of CSR in Asia Will Be Enhanced by Globalization}

We investigate the relationship between globalization and CSR through three indicators: levels of direct foreign investment, international export patterns, and the domestic/international status of companies.

First, we consider the possible effect of foreign direct investment into a country on its level of CSR penetration. Figure 2 provides some evidence of an association between CSR and globalization as measured by direct foreign investment into each country (a Spearman nonparametric correlation revealed a .71 correlation coefficient significant at the .05 level). Once again, India and Singapore are anomalies. India has a high CSR reporting score but relatively low foreign direct 


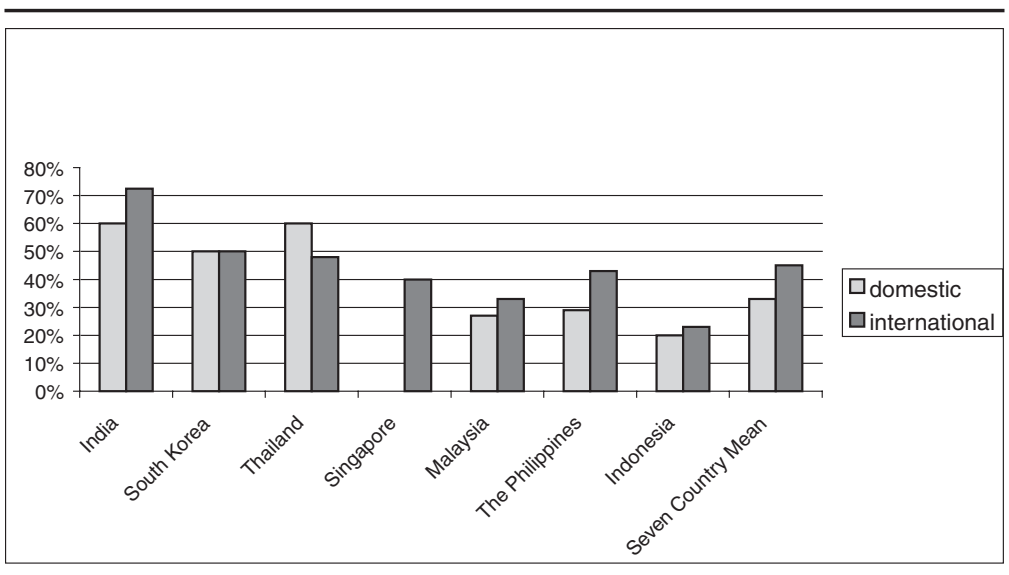

Figure 3. Penetration of Corporate Social Responsibility by Domestic and International Companies

investment. Singapore has only average CSR penetration but relatively high foreign direct investment.

Second, we examined whether levels of CSR are correlated with the identity of the countries (Western/non-Western) with which a company trades on the assumption that countries that trade more with Westernized countries might be expected to raise their levels of CSR (one explanation of CSR development in Japan; see Fukukawa \& Moon, 2004). However, we found no uniform pattern, and a Spearman correlation confirms no statistical significance.

Third, we investigated the explanatory significance of domestic and international nationality of the companies that were classified as medium or extensive in their CSR reporting (Table 1). The domestic cohort consists of companies that are headquartered within the country in question and operate solely therein. The international cohort consists of two types of company: (a) those that are headquartered within the country in question and that operate in or export to other countries and (b) those headquartered in another country and operate in the country in question (although there were only 3 and 4 domestic companies in Singapore and South Korea, respectively; in the other countries, between 10 and 32 companies were classified as domestic).

Figure 3 indicates that overall and in most individual countries, the international cohort is associated with higher levels of CSR penetration. Thus, we are unable to reject the hypothesis that CSR is positively associated with globalization. It should be noted that this is not necessarily a Western versus Asian point. Many of the domestically owned companies 
Table 4

Corporate Social Responsibility Issues Reported Across Seven Asian Countries by Domestic and International Companies

\begin{tabular}{|c|c|c|}
\hline Issues & Domestic \% & International \% \\
\hline \multicolumn{3}{|l|}{ Community Involvement } \\
\hline General & 7 & 6 \\
\hline Agriculture, local economic development & 6 & 5 \\
\hline Arts, culture & 4 & 6 \\
\hline Community development & 10 & 8 \\
\hline Education, training & 20 & 15 \\
\hline Environment, conservation & 13 & 13 \\
\hline Health, disability & 6 & 7 \\
\hline Housing & 0 & 1 \\
\hline Religious & 2 & 4 \\
\hline Sport & 2 & 7 \\
\hline Welfare (including poverty, emergency relief) & 2 & 6 \\
\hline Youth, children & 4 & 2 \\
\hline Other & 2 & 1 \\
\hline \multicolumn{3}{|l|}{ Socially responsible products } \\
\hline Environment & 9 & 8 \\
\hline Health and safety & 6 & 4 \\
\hline Human resources & 3 & 3 \\
\hline Ethics & 1 & 1 \\
\hline \multicolumn{3}{|l|}{ Employee relations } \\
\hline Employee welfare & 3 & 4 \\
\hline Employee engagement & 0 & 1 \\
\hline
\end{tabular}

with international operations traded exclusively with other Asian countries. Many of the foreign-owned companies were based in other Asian countries. However, it does highlight that at the firm level, there is a stronger relationship between international exposure, be it in the form of international sales or foreign ownership, and higher levels of CSR reporting.

Hypothesis 4: National Business Systems Structure the Profile of MNCs' CSR

The question then arises as to whether, if international companies are providing key drivers for CSR in Asia, this entails the importation of foreign CSR issues and modes. Our findings suggest otherwise. Table 4 indicates that the distribution of patterns of commitment to CSR issues among international and domestic companies is very similar.

Table 5 indicates that the CSR modes chosen by domestic and international companies are also broadly similar. One difference worth mention- 
Table 5

Corporate Social Responsibility (CSR) Modes Across Seven Asian Countries Reported by Domestic (D) and International (I) Companies

\begin{tabular}{|c|c|c|c|c|c|c|}
\hline \multirow[b]{3}{*}{ CSR Modes } & \multicolumn{6}{|c|}{ CSR Waves } \\
\hline & \multicolumn{2}{|c|}{$\begin{array}{l}\text { Community } \\
\text { Involvement }\end{array}$} & \multicolumn{2}{|c|}{$\begin{array}{c}\text { Socially } \\
\text { Responsible Products }\end{array}$} & \multicolumn{2}{|c|}{$\begin{array}{l}\text { Employee } \\
\text { Relations }\end{array}$} \\
\hline & $D \%$ & $I \%$ & $D \%$ & $I \%$ & $D \%$ & $I \%$ \\
\hline Foundation & 20 & 14 & 0 & 0 & 16 & 3 \\
\hline Volunteering & 1 & 5 & 0 & 0 & 18 & 0 \\
\hline Codes, policies, systems & 0 & 1 & 100 & 98 & 0 & 15 \\
\hline Sponsorship & 3 & 5 & 0 & 1 & 0 & 0 \\
\hline Partnerships & 21 & 16 & 0 & 1 & 0 & 3 \\
\hline Philanthropy & 54 & 60 & 0 & 1 & 65 & 79 \\
\hline
\end{tabular}

ing, however, is the greater frequency of international companies using employee codes than the domestic ones that are more likely to use employee foundations.

Although the evidence suggests that national levels of CSR are enhanced by international exposure (Hypothesis 3), it does not follow that international companies impose a profile of CSR on their host countries. On the contrary, it appears as if they conform to the respective national profiles. Therefore, we cannot reject the hypothesis that national business systems structure the profile of MNCs' CSR.

\section{CONCLUSION}

Our results have failed to reject our first hypothesis that CSR varies among Asian countries. This was demonstrated in terms of its penetration, extent, and profile as indicated by CSR waves and issues. The only indicator for which the hypothesis was rejected was that of CSR modes that appeared to be relatively similar with a great emphasis on the philanthropic rather than the systematic or institutionalized.

Having confirmed that there is no single pattern of CSR in Asia, the question then arises as to what explains the variation. Our second hypothesis addressed this by investigating the explanatory significance of three indicators of development-economic development, economic sectors, and social development. Our results required that we reject the hypothesis, and we suggested instead that CSR might be better explained by national factors. This is a form of explanation used in accounts of comparative public policy profiles (e.g., Castles, 1989) and national business 
systems (e.g., Whitley, 1992). To demonstrate this conclusively requires a rather different sort of analysis than the scope in this study, but consideration of the cases of India and Singapore illustrates our proposition.

The finding for India is precisely opposite to the assumption that CSR is a function of development. India has the lowest level of GNP per capita of the sample and the highest level of CSR within the sample. India's CSR is in part associated with long-standing, religiously derived, philanthropic traditions. But it has also been associated with earlier epochs of the internationalization of business, colonization, and imperialism. As a result, India has the longest standing and most substantial experience of the impact of foreign firms. Although their behavior would not necessarily meet contemporary criteria of social responsibility, there was a sense, particularly in the case of the East India Company, that business success included social management (Mohan, 2001). The growth of Indian indigenous business in the interwar period was associated with social and religious reform (Mohan, 2001), and norms of business philanthropy appear well established today. For example, in a survey on the perceptions of Indian businesses on CSR, every single respondent claimed that the characteristics of a successful modern Indian company are related to a company's social and environmental performance (Brown, 2001).

In contrast, Singapore easily has the highest levels of economic and social development of the sample but is ranked only fourth in our findings on CSR penetration. Moreover, it is ranked seventh in the rankings of countries on the indicator of extensive CSR coverage (Table 2). This confirms Roche's (2000) conclusion that although academic studies in Western companies demonstrate that CSR and increased profits go very well together, this is not yet recognized — let alone quantified—in Singapore.

One explanation for this finding is Singapore's relatively large tax base enabling its government to invest heavily on behalf of Singapore citizens into such areas as education and environmental protection, thus removing the need and stimulus for Singaporean companies to do so themselves (Roche, 2000). Related to this, it could be argued that Singapore does not experience the sort of deleterious social conditions that, elsewhere, are drivers for CSR. Its economic success results in a minimal level of unemployment, thus removing the need for many community involvement activities. As it is so small in land area and has no agricultural sector, many environmental issues that face other larger countries do not apply to Singapore. But even if this explanation, that wealth dilutes the imperatives for CSR, has some empirical resonance in Singapore, it is hardly generalizable given that the countries most closely associated with CSR companies - the United States, the United Kingdom, and Japan—have yet higher tax bases. 
Turning to the third hypothesis, we investigated whether CSR is enhanced by globalization. Our first test of the significance of the overall national levels of direct foreign investment for CSR yielded a weak relationship. Perhaps the most significant finding here tends to add credence to the second hypothesis that the country with the lowest scores on direct foreign investment, India, had the highest CSR penetration score. There was no relationship found in our second test of the significance of trading partners for CSR. The third test, which is the most apposite in view of the theories of concerning strategies for globalization of companies, was of a positive relationship. Companies designated as international were clearly more likely to report their CSR than those designated as domestic. As many of these international companies are Asian, the findings suggest that this is not simply an indicator of Western companies having more advanced CSR than their Asian counterparts but, rather, a question of the imperatives of crossing borders. Thus, we were not able to reject the hypothesis. This conclusion highlights that at the firm level, there is a relationship between international exposure, be it in the form of international sales or foreign ownership, and higher levels of CSR adoption. This could be taken to provide some support for Porter and Van der Linde (1995) who stated that those firms that are exposed to international competition are likely to have higher (environmental) standards. This relationship can be extended to wider social responsibility issues. It can also be argued that firms with an international market would have a broader range of stakeholders. As firms cross borders, there is a stakeholder multiplier effect, and hence, it is in the interests of the company to engage in CSR and to communicate it through the Web.

Notwithstanding the finding that companies crossing borders are more likely than others to become CSR companies, our investigation of the fourth hypothesis revealed that this does not necessarily mean that international companies impose their own CSR profiles in countries in which they operate. This echoes findings from Australia of non-Australianbased companies conforming with the CSR issues that Australian-based companies both engaged in and prioritized (Moon \& Sochacki, 1995).

A number of questions arise from our research. It could be objected that the findings mask sectoral issues. In other words, what seem like national findings may actually reflect the sectoral identities of the top 50 companies in each country. Further research could also investigate the different levels of risk with which each company is associated. For example, many large companies are located in the chemical and oil industries, which have higher risk, and distinct CSR issues associated with them.

Although multinational comparative studies offer the advantages of a high number of cases, a check against conclusions based on single 
systems, and the ability to test explanatory variables, they also bring weaknesses. The most obvious disadvantage is that nuances of national systems are lost as the comparative design narrows the analytical range into a small number of variables derived from a common source: Web site reports. Clearly, there is scope for case study research to follow up our conclusions. In particular, research could address relationships between CSR profiles and corporate governance and public policy settings in each country. It could also explore the different meanings of CSR that lie behind the national profiles.

The finding of the positive association between globalization and CSR raises a number of further questions for research. At the macro level, the significance of the balance of nationalities represented in the firms described as international could be investigated. Secondly, at the micro level, there is scope for research on the particular strategies that have informed the decisions to take CSR to foreign countries or to bring CSR from foreign countries.

Clearly, the relationships between the national profiles of CSR and the respective national business systems and between globalization and national profiles of CSR need further research. This article has provided some initial, empirically based findings on which this further research can build.

\section{REFERENCES}

Adams, C. A., Hill, W. Y., \& Roberts, C. B. (1998). Corporate social reporting practices in Western European: Legitimating corporate behaviour? British Accounting Review, $30(1), 1-21$

Belson, K. (2000, October 23). Asia's Internet deficit. Business Week, pp. 1-6.

Birch, D., \& Moon, J. (Eds.). (2004). CSR in Asia [Special issue]. Journal of Corporate Citizenship, 13.

Braithewaite, J., \& Drahos, P. (2000). Global business regulation. Cambridge, UK: Cambridge University Press.

Brown, K. (2001). Corporate social responsibility: Perceptions of Indian business. London: Centre for Social Markets.

Carroll, A. B. (1998). The four faces of corporate citizenship. Business and Society Review, $100(1), 1-7$.

Castles, F. (1989). The history of public policy. Cambridge, UK: Polity Press.

Central Intelligence Agency. (2000). The world factbook. Retrieved August 27, 2002, from www.gov/cia/publicaations/factbook/geos

Crook, C. (2005, January 22). The good company. The Economist, pp. 1-18.

Davies, R. (2000). Why Asian business has to care about poverty. Retrieved August 28, 2002, from http:/pwblf.org/csr/csrwebassist.nsf/webprintview/f1d2b3u4.html 
de la Torre, J., \& Moxon, R. W. (2001). E-commerce and global business: The impact of the information and communication technology revolution on the conduct of international business. Journal of International Business Studies, 32(4), 617-639.

Esrock, S. L., \& Leichty, G. B. (1998). Social responsibility and corporate Web pages: Self presentations or agenda-setting? Public Relations Review, 24(3), 327-344.

Fukukawa, K., \& Moon, J. (2004). A Japanese model of corporate social responsibility? A study of online reporting. Journal of Corporate Citizenship, 14, 45-59.

Glaser, B. G., \& Strauss, A. L (1967). The discovery of grounded theory. Chicago: Aldine.

Habisch, A., Jonker, J., Wegner, M., \& Schmidpeter, R. (Eds.). (2004). CSR across Europe. Berlin, Germany: Springer-Verlag.

Hooghiemstra, R. (2000). Corporate communication and impression management-new perspectives why companies engage in corporate social reporting. Journal of Business Ethics, 27(1), 55-68.

Johnson, G. (2000, July 10). Asia faces Internet challenges. Electronic News, pp. 1-3.

Kemp, M. (2001). Corporate social responsibility in Indonesia: Quixotic dream or confident expectation? [Program Paper No. 6]. Geneva, Switzerland: United Nations Research Institute for Social Development.

KPMG. (2005). KPMG international survey of corporate responsibility reporting 2005. Amsterdam, the Netherlands: KPMG Global Sustainability Services.

Langlois, C. C., \& Schlegelmilch, B. B. (1990). Do corporate codes of ethics reflect national character? Evidence from Europe and the United States. Journal of International Business Studies, 21(4), 519-539.

Maignon, I., \& Ralston, D. A. (2002). Corporate social responsibility in Europe and the U.S.: Insights from businesses' self-presentations. Journal of International Business Studies, 33(3), 497-514.

Mallin, C. (2004). Corporate governance. Oxford, UK: Oxford University Press.

Matten, D., \& Moon, J. (2004). "Implicit" and "explicit" CSR: A conceptual framework for understanding CSR in Europe. In A. Habisch, J. Jonker, M. Wegner, \& R. Schmidpeter (Eds.), CSR across Europe (pp. 335-356). Berlin, Germany: Springer-Verlag.

Maurice, M., \& Sorge, A. (Eds.). (2000). Embedding organisations: Societal analysis of actors, organisations and socio-economic context. Amsterdam, the Netherlands: John Benjamins.

McIntosh, M., Waddock, S., \& Kell, G. (Eds.). (2004). Learning to talk: Corporate citizenship and the development of the UN global compact. Sheffield, UK: Greenleaf.

McWilliams, A., \& Siegel, D. (2001). Corporate social responsibility: A theory of the firm perspective. Academy of Management Review, 26, 117-127.

Mohan, A. (2001). Corporate citizenship: Perspectives from India. Journal of Corporate Citizenship, 2, 107-117.

Moon, J. (2002). Corporate social responsibility: An overview. In International directory of corporate philanthropy (pp. 3-14). London: Europa.

Moon, J. (2003). Socializing business? Government and Opposition, 38(3), 265-273.

Moon, J. (2004). Government as a driver of corporate social responsibility: The UK in comparative perspective [International Centre for Corporate Social Responsibility Research Paper No. 20]. Nottingham, UK: Nottingham University Business School.

Moon, J., \& Sochacki, R. (1995). The social responsibility of business in job and enterprise creation. Crawley, Australia: Department of Political Science, University of Western Australia.

Perelmutter, H. (1969). The tortuous evolution of the multinational corporations. The Columbia Journal of World Business, 4, 9-18. 
Porter, M., \& Van der Linde, C. (1995). Toward a new conception of the environmentcompetitiveness relationship. Journal of Economic Perspectives, 9(4), 97-118.

Ramasamy, B., \& Woan Ting, H. (2004). A comparative analysis of corporate social responsibility awareness: Malaysia and Singapore. Journal of Corporate Citizenship, 13, 109123.

Roche, J. (2000). Singapore: Corporate, social \& responsible but no corporate social responsibility. Retrieved September 2, 2002, from www.csmworld.org/csr_singapore .htm

Rodan, G. (2002). Do markets need transparency? The pivotal cases of Singapore and Malaysia. New Political Economy, 7(1), 23-47.

Rossouw, G. (2005). Business ethics and corporate governance in Africa. Business and Society, 44(1), 94-106.

Ryan, L. V. (2005). Corporate governance and business ethics in North America. Business and Society, 44(1), 40-73.

Sharfman, M., Shaft, T., \& Tihanyi, L. (2004). A model of the global and institutional antecedents of high level corporate environmental performance. Business \& Society, 43(1), 636.

Van Tulder, R., \& Kolk, A. (2001). Multinationality and corporate ethics: Codes of conduct in the sporting goods industry. Journal of International Business Studies, 32(2), 267-283.

Welford, R. (2004). Corporate social responsibility in Europe and Asia: Critical elements and best practice. Journal of Corporate Citizenship, 13, 31-47.

Whitley, R. (Ed.). (1992). European business systems. London: Sage.

Whitley, R. (1999). Divergent capitalisms: The social structuring and change of business systems. Oxford, UK: Oxford University Press.

Whitley, R. (Ed.). (2002). Competing capitalisms: Institutions and economics. Cheltenham, UK: Edward Elgar.

Wieland, J. (2005). Corporate governance, values management, and standards: A European perspective. Business and Society, 44, 174-193.

Wolf, M. (2002). Response to "Confronting the Critics." New Academy Review, 1(1), 62-65.

Wendy Chapple is a lecturer in industrial economics in the Nottingham University Business School and deputy director of the International Centre for Corporate Social Responsibility. Her current research includes the relationship between national business systems and corporate social performance and the economics of corporate social responsibility.E-mail: wendy.chapple@nottingham.ac.uk.

Jeremy Moon is a professor and director of the International Centre for Corporate Social Responsibility, Nottingham University Business School. His research includes the relationship between corporate social responsibility and government. He is currently cowriting Corporations and Citizenship for Cambridge University Press.E-mail: jeremy.moon@nottingham.ac.uk. 